\title{
Weather regimes and analogues downscaling of seasonal precipitation for the 21st century: A case study over Israel
}

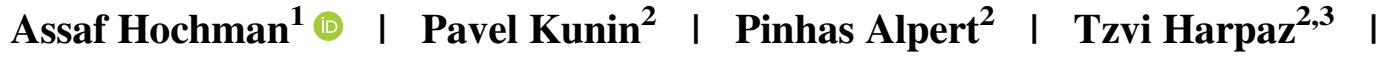 \\ Hadas Saaroni $^{3}$ () । Dorita Rostkier-Edelstein ${ }^{4,5}$ (1)
}

${ }^{1}$ Department of Tropospheric Research, Institute of Meteorology and Climate Research, Karlsruhe Institute of Technology, Eggenstein-Leopoldshafen, Germany

${ }^{2}$ Department of Geophysics, Porter School of Environment and Earth Sciences, TelAviv University, Tel-Aviv, Israel

${ }^{3}$ Department of Geography and the Human Environment, Porter School of Environment and Earth Sciences, Tel-Aviv University, Tel-Aviv, Israel

${ }^{4}$ Department of Applied Mathematics, Environmental Sciences Division, Israel Institute for Biological Research, Ness-

Ziona, Israel

${ }^{5}$ Fredy and Nadine Herrmann Institute of Earth Sciences, the Hebrew University of Jerusalem, Edmond J. Safra Campus, Jerusalem, 9190401, Israel

\section{Correspondence}

Assaf Hochman, Department of Tropospheric Research, Institute of Meteorology and Climate Research, Karlsruhe Institute of Technology, Eggenstein-Leopoldshafen, Germany Email: assaf.hochman@kit.edu

\section{Funding information}

Israel Science Foundation, Grant/Award

Number: 1123/17; Helmholtz Association

\begin{abstract}
Global climate models provide only partial information on local-scale phenomenon, such as precipitation, primarily due to their coarse resolution. In this study, statistical downscaling algorithms, based on both weather regimes and past analogues, are operated for 18 Israeli rain gauges with an altitude ranging between -200 and $\sim 1,000 \mathrm{~m}$ above sea level (ASL). To project seasonal precipitation over Israel and its hydrologic basins, the algorithms are applied to six Coupled Model Inter-comparison Project Phase 5 (CMIP5) models for the end of the 21st century, according to the RCP4.5 and RCP8.5 scenarios. The downscaled models can capture quite well the seasonal precipitation distribution, though with underestimation in winter and overestimation in spring. All models display a significant reduction of seasonal precipitation for the 21 st century according to both scenarios. The winter reductions for the end of the century and the RCP8.5 scenario are found to be $\sim 22$ and $\sim 37 \%$ according to the weather regimes and the analogues downscaling methods, respectively. Spring reductions are found to be $\sim 10-20 \%$ larger than winter reductions. It is shown that the projected reduction results from a decrease in the frequency of the rain-bearing systems, as well as a decrease in the average daily precipitation intensity. The areas with the largest reductions in seasonal precipitation are found over the central mountains, the Mediterranean coastal area, and the Sea of Galilee hydrologic basins, which are the main fresh-water aquifers and reservoirs of Israel. The statistical downscaling methods applied in this study can be easily transferred to other regions where long-term data sets of observed precipitation are available. This study and others may serve as a basis for priority and policy setting toward better climate adaptation with associated uncertainties related to the methods used and nonstationary of the climate system.
\end{abstract}

\section{KE Y WOR D S}

analogues downscaling, climate change, CMIP5 predictions, Eastern Mediterranean, seasonal precipitation, synoptic classification, weather regimes 


\section{1 | INTRODUCTION}

Careful planning of water resources is critical in regions suffering from water shortage and large interannual precipitation variability. The eastern Mediterranean region and the Middle East exhibit these conditions, as located at the border between temperate (Mediterranean) and arid climates (Zhang et al., 2005, Saaroni et al., 2010a; Morin, 2011). The complex terrain and the sharp transition from coastal to continental and arid areas result in large spatial variability in seasonal precipitation (see the rainfall map of Israel, Israel Meteorological Service (IMS) 2018, Climate Atlas of Israel; Saaroni et al., 2010a).

Future projections of seasonal precipitation are generated by climate models. While global circulation models (GCMs) are a comprehensive tool for studying climate conditions and even local regimes, they have often been criticized when used for modeling the complex climate regime of the Mediterranean region (e.g., Lionello et al., 2014). The main concern is the coarse resolution of the models that is problematic in identifying mesoscale processes and especially local weather conditions. Although improvement in these models is well seen, most GCMs still have a horizontal resolution of a few hundreds of kilometers. This prevents them from capturing the effects of local forcing, for example, complex terrain, urban effects and sea-land interactions (Giorgi et al., 2009; Giorgi and Gutowski, 2015; Maraun \& Widmann, 2018). In order to bridge the gap between GCMs and local climate variables, several downscaling methods have been developed (e.g., Wilby and Wigley, 1997; Maraun et al., 2010; Maraun \& Widmann, 2018).

There are three main approaches for downscaling GCMs; the first is a dynamical approach, where GCM outputs are used to force regional models that can better represent the physical and dynamical characteristics of the specific region due to their higher resolution. The second is a statistical approach; developing statistical relations between atmospheric conditions at the grid points of the GCMs used and the observed local conditions. The third is a weather regime downscaling approach; classifying GCM outputs to a limited number of weather regimes or analogues (Giorgi and Gutowski, 2015).

The advantages and disadvantages of these approaches have been extensively discussed, concluding that the various methods should be used due to the different strengths and weaknesses each method has (e.g., Fowler et al., 2007; Laprise et al., 2008; Warner, 2011; Maraun et al., 2015; Velasquez et al., 2015; Salvi et al., 2016; Lanzante et al., 2018). As opposed to dynamical downscaling, which is computationally demanding, statistical downscaling methods are computationally inexpensive and often, but not always, provide good results, depending on the availability of high- quality observations and the specific methodologies of the statistical techniques (Lanzante et al., 2018). Nevertheless, statistical downscaling, adopted in this study, may suffer from a few sources of uncertainty: (a) the downscaling method itself can be a considerable source of uncertainty (Maraun et al., 2015). (b) Statistical downscaling, being empirically based, may be even more sensitive to the nonstationary of the climate system compared to dynamical downscaling. This is because the empirical relations, which are based on observations, are assumed to be stationary over time (Salvi et al., 2016). (c) Bias correction under nonstationary bias may also be a source of uncertainty (Velasquez et al., 2015). (d) The uncertainty emerging from the stochastic nature of the climate (Peleg et al., 2019).

Both dynamical and statistical downscaling methods have been extensively applied to address various climate related issues and have become an important tool in climate change research. However, until recent years, the downscaled products were still underrepresented in climate change assessment reports on both global and regional scales. For this reason, coordinated frameworks, such as CORDEX (Giorgi et al., 2009) and COST-VALUE (Maraun et al., 2015; Huth, 2019) were established, aiming to evaluate downscaling techniques and provide an ensemble of future projections for the community to make use of.

Over the eastern Mediterranean and Israel a few downscaling studies were published in the recent years. Alpert et al. (2008), using regional climate simulations, reported a $30-75 \mathrm{~mm}$ reduction in winter precipitation in Israel when comparing 2071-2100 with 1961-1990, according to the A2 scenario. Önol and Semazzi (2009), using a regional climate simulation, predicted a decrease in winter precipitation of 24\% over the eastern Mediterranean for the end of the twenty-first century, according to the A2 scenario. Hochman et al. (2018a) using a regional high-resolution, of $\sim 8 \mathrm{~km}$, model have predicted a reduction in seasonal precipitation of $\sim 40 \%$ in the northern and central parts of Israel at mid-21st century, according to the RCP4.5 scenario. It can be concluded that there is widespread agreement regarding negative trends projected for precipitation over Israel and the Levant, as can be inferred from the aforementioned studies and others (Black, 2009; Chenoweth et al., 2011; Evans, 2010; Lelieveld et al., 2012; Samuels et al., 2013; Peleg et al., 2015).

The rainy season in Israel is between October and May, contributing $~ 90 \%$ of the annual rainfall and about $2 / 3$ of the rain is concentrated in the mid-winter months (DJF, Goldriech, 2003; Saaroni et al., 2010a). The region's climate is intensely affected by external forcing of both mid-latitude and tropical origins (e.g., Alpert et al., 2005). However, the rain in the Mediterranean part of Israel results mainly from passage or development of extratropical cyclones over the 


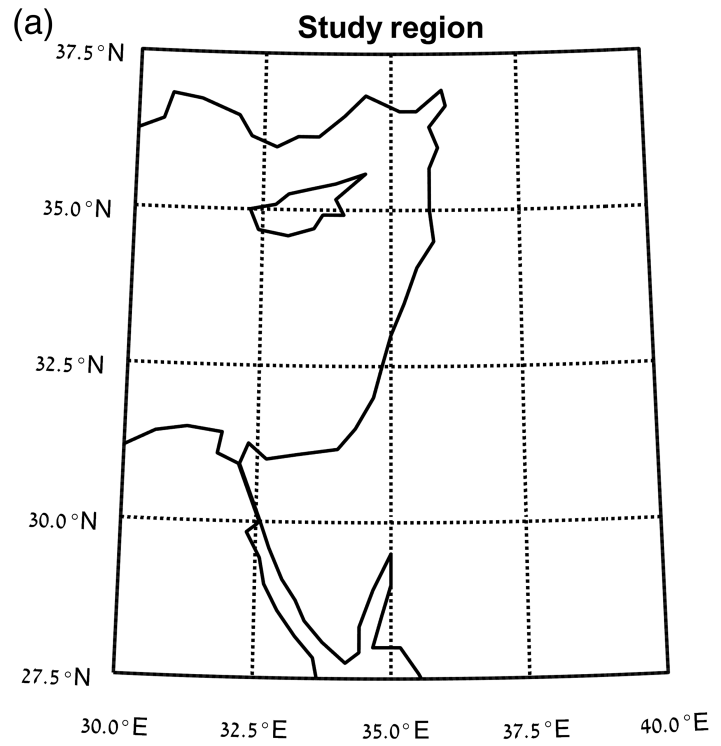

(b)

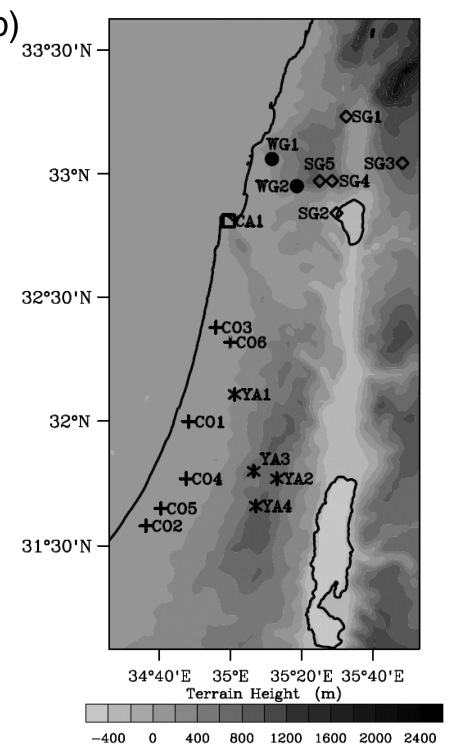

F IG URE 1 The study region. (a) The 25 grid points used for the synoptic classification of the Levant according to Alpert et al. (2004a). (b) The location of the 18 selected rain stations on the top of the topography. Different symbols and naming are used to present the hydrologic basins: Coastal (+CO), Carmel ( $\square$ CA), Western Galilee (@WG), Sea of Galilee/Kinneret ( $\diamond \mathrm{SG})$, and Mountain/Yartan (*YA). In the present study, the Carmel (CA) station is associated to the Western Galilee (WG) basin (reproduced from RostkierEdelstein et al., 2016) eastern Mediterranean, known as the Cyprus Lows (HMSO, 1962; Sharon and Kutiel, 1986; Alpert et al., 1990; Shay-El and Alpert, 1991; Trigo et al., 1999; Schädler and Sasse, 2006; Ziv et al., 2006, 2015). Saaroni et al. (2010a) found that the average contribution of Cyprus Lows to the rainfall in Israel is $83 \%$. The rain regime is characterized by relatively limited number of rainy days ( $\sim 50$ days; www.ims. gov.il), implying relatively high intensity of daily rain. This is accompanied with large inter and intraseasonal variations, including prolonging dry spells within the rainy season (Alpert, 1991; Saaroni et al., 2015, 2019).

The spatial distribution of the rainfall in Israel is largely dominated by three geographic factors: a decrease from north to south, exhibiting the transition from a Mediterranean regime to an arid one; a decrease from west to east when moving away from the Mediterranean Sea, and an increase with elevation due to orography (Katsnelson, 1964; Diskin, 1970; Kutiel, 1987; Goldreich et al., 2004). The reader is referred to Figure 1 in Saaroni et al. (2010a) for the spatial distribution of annual average precipitation over Israel and to the climate atlas of Israel (http://www.ims.gov. il/NR/rdonlyres/FEE1B975-72C5-45EF-B67A-

672FC83C6FE2/0/\%D7\%9E\%D7\%A4\%D7\%95\%D7\%AA\% D7\%9E\%D7\%A9\%D7\%A7\%D7\%A2\%D7\%99\%D7\% 9D19812010.pdf).

Based on the rainfall distribution, the Israeli Hydrological Service has defined five regions of interest: the first refers to the entire region of Israel and the other four refer to the large hydrologic basins: Western Galilee, Sea of Galilee, the coast and the mountains (Figure 1b; reproduced from RostkierEdelstein et al., 2016). These basins differ in their seasonal precipitation amounts and temporal distribution.

The synoptic systems, being responsible for the weather regimes over the eastern Mediterranean, are well described by the semiobjective synoptic classification of Alpert et al. (2004a). The classification is based on the geopotential height, temperature, and two horizontal wind components $U$ and $V$ at the $1,000 \mathrm{hPa}$ level, in 25 grid points $\left[27.5^{\circ} \mathrm{N}\right.$ $\left.37.5^{\circ} \mathrm{N} ; 30^{\circ} \mathrm{E}-40^{\circ} \mathrm{E}\right]$ (Figure 1a; Alpert et al., 2004a). A team of expert weather forecasters, as specified in Alpert et al. (2004a), have first defined five main synoptic systems characterizing the region, further divided into 19 specific synoptic types. The five main systems are the Persian Trough, characterizing the summer, the Cyprus Low being dominant in winter, the Red Sea Trough peaking in autumn, the "Sharav" Low (North African Low) that peaks during spring and high-pressure systems that exist in all seasons. This classification successfully describes the local weather conditions as well as various environmental phenomenon as dust, floods and air pollution (e.g., Dayan et al., 2012; Saaroni et al., 2010a, 2010b, 2010c). This classification has been successfully used to define the seasons over the eastern Mediterranean (Alpert et al., 2004b), to project seasons' length changes for the 21st century (Hochman et al., 2018b) and to diagnose future changes in the local atmospheric dynamics of the synoptic systems (Hochman et al., 2018c, 2019), as well as many other applications. Hochman et al. (2018c) have projected a $\sim 30 \%$ decrease in the number of Cyprus Lows by the end of the 21 st century under the RCP8.5 scenario.

Rostkier-Edelstein et al. (2016) developed a statistical downscaling methodology for seasonal precipitation in Israel based on this semiobjective synoptic classification. They have also proposed a direct use of selected analogues, as originally proposed by Lorenz (1969). In the analogue method, a large-scale daily weather state is compared with those from a past long-term record. Then, according to a selected metric, the most similar state from the past is identified, and the corresponding observations (of daily precipitation, for example) are selected as prediction for the weather 
(Zorita and von Storch, 1999; Rostkier-Edelstein et al., 2016). Both the analogues and the weather regime methods were found to provide good skill in predicting the mean seasonal precipitation amounts and the quantiles of winter precipitation distribution, as well as in reproducing the observed interannual and spatial variability of the seasonal precipitation in Israel. These methods, using the NCEP/ NCAR reanalysis downscaled with respect to the 18 rain stations used in this study, for the period 1991-2008 showed good correlations ( $R=\sim 0.8$, cross-validated and seasonally aggregated). Moreover, the analogues and the weather regime methods were used to downscale NCEP-CFS1.0 global seasonal forecasts (Saha et al., 2006), with similar skill. The downscaled precipitation reproduced well the observed spatial variability, which the coarse global models could not capture (Rostkier-Edelstein et al., 2016).

The purpose of the present study is to apply the abovementioned two statistical downscaling methodologies to the 21st century CMIP5 outputs to project the seasonal precipitation over Israel and over its four main hydrologic basins. The data used are provided in Section 2. The weather regime and analogues downscaling algorithms are specified in Section 3. The results of the seasonal precipitation downscaling over Israel, and the 21 st century ensemble projections are presented in Section 4. Section 5 summarizes and concludes.

\section{2 | DATA}

Reanalysis data were acquired from the National Center for Environmental Prediction/National Center for Atmospheric Research Reanalysis Project (NCEP/NCAR; Kalnay et al., 1996). This database is available on daily or 6-hr time scales from 1948 -present, on a $2.5^{\circ} \times 2.5^{\circ}$ grid spacing.

Modeled data for six models participating in the fifth phase of the Coupled Model Inter-Comparison Project (CMIP5; Taylor et al., 2012) were retrieved from the World Data Center for Climate (WDCC-DKRZ, http://cera-www. dkrz.de/WDCC/ui/Index.jsp) data portal. These models were previously utilized in Hochman et al. (2018b, c, and 2019) (list of models see Table 1) and their ability to simulate annual and extreme precipitation indices over the eastern Mediterranean was previously presented by Samuels et al. (2017). Furthermore, these models' ability to simulate the annual cycle of the prevailing eastern Mediterranean synoptic systems, their frequencies, and dynamics for the historical period were presented in Hochman et al. (2018b, c, and 2019). These authors concluded that the evaluation of CMIP5 models suggests that the models capture a number of the salient qualitative features found in reanalysis data. At the same time, they may fail to reproduce a number of the reanalysis' quantitative features. This may result from a few reasons: First, reanalysis includes assimilation of observations, which climate models do not. This is done in order to assure that the model is as close to reality as possible. Second, reanalysis is derived through running weather forecast models and therefore, the climate is recovered as a compilation of many weather events that truly occur, which is not the case in climate models. Third, reanalysis is usually run at a higher resolution than climate models. Thus, climate models simulate their own climate that may show larger bias and random errors than reanalysis show with respect to observations (Warner, 2010). In addition, there are several processes, which are known to exert a strong control over the eastern Mediterranean weather and climate; These include large-scale teleconnections, as the North Atlantic Oscillation (NAO) or the Indian Monsoon (Alpert et al., 2005), as well as local processes such as sea surface fluxes over the eastern Mediterranean (Stein and Alpert, 1991). Both sets of features may not be well simulated by some of the models (Stein and Alpert, 1991; Sperber et al., 2013; Davini and Cagnazzo, 2014), thus leading to some errors in the diagnostics of the regional synoptic systems.

Models' data are available on daily time scales for 1861-2100. Spatial resolutions vary in range from $1.12^{\circ}$ $\times 1.13^{\circ}$ to $2.79^{\circ} \times 2.81^{\circ}$ (Table 1 ). The analysis representing the present period is based on the "historical" (1986-2005) simulations of the six CMIP5 models (Table 1) as well as on the NCEP/NCAR reanalysis archive. Future periods simulated are the mid-21st-century (2046-2065) and the end of the 21 st century (2081-2100). This is done for two representative concentration pathways of $8.5 \mathrm{~W} / \mathrm{m}^{2}$ (RCP8.5) and $4.5 \mathrm{~W} / \mathrm{m}^{2}$ (RCP4.5) scenarios, following the recommendation of the Fifth Assessment Report (AR5) of the Intergovernmental Panel on Climate Change (IPCC, 2013). For a more complete explanation of the RCP scenarios, the reader is referred to Van-Vuuren et al. (2011).

The statistical downscaling algorithms in the current study require historical records of daily precipitation observations. A set of 18 selected stations for the period 1991-2008 are used, providing a continuous archive of daily precipitation that has undergone a quality assurance procedure (Table S1). Figure 1b displays the location of the stations with respect to the main hydrologic basins of Israel.

\section{3 | METHODS}

\section{1 | Modified synoptic classification}

The synoptic classification algorithm, developed by Alpert et al. (2004a), is applied to the above-mentioned CMIP5 models, in order to downscale seasonal precipitation for the 21 st century (for a description of the synoptic classification method see Section 1). The 12UTC data are a prerequisite 
T A B L E 1 The six CMIP5 models used indicating: the modeling center (or group), the institute ID, the model name and its horizontal resolution $\left({ }^{\circ}\right)$, following Taylor et al. (2012)

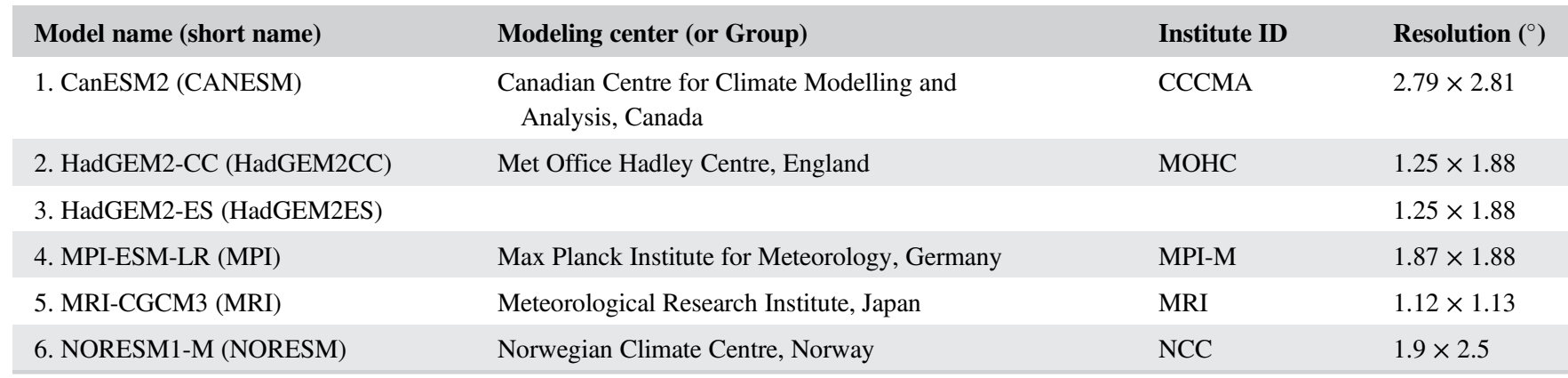

for the synoptic classification algorithm of Alpert et al., (2004a). Moreover, the purpose here was to minimize the difference between the original algorithm (applied to NCEP/ NCAR reanalysis) and the new one (applied to CMIP5 models). The models' data are available in a variety of spatial resolutions (Table 1), therefore, they were linearly interpolated to fit the required 25 grid points $\left[27.5^{\circ} \mathrm{N}-37.5^{\circ} \mathrm{N}\right.$; $\left.30^{\circ} \mathrm{E}-40^{\circ} \mathrm{E}\right]$ used by Alpert et al., (2004a) (Figure 1a).

Due to the absence of 12UTC data at the 1,000-hPa level in CMIP5 models, we use $\mathrm{U}$ and $\mathrm{V}$ wind components and temperature from the $850-\mathrm{hPa}$ level, as well as sea level pressure (SLP). The compatibility between the 1,000 and the 850-hPa levels, and that of the 12UTC with daily classifications was examined by Hochman et al. $(2018 \mathrm{~b}$, c) and Berkovic (2016), respectively, and was shown to fit well. Nevertheless, the ability of the two downscaling methods used, that is, the modified algorithm for the synoptic classification (the "weather regimes") and the "analogues" to downscale observed seasonal precipitation is evaluated here for both the NCEP/NCAR reanalysis and the CMIP5 models.

The downscaling methods, applied for the present evaluation and for future projection of seasonal precipitation over Israel and over its hydrologic basins, are identical to the algorithms described in Rostkier-Edelstein et al. (2016) and are described in the next section.

\section{2 | Weather regime and analogues downscaling}

The weather regime downscaling algorithm is based on the modified synoptic classification algorithm (described above), computing the frequency of each of the 19 weather regimes (following the synoptic types defined by Alpert et al., 2004a). The U and V wind components and the temperature at the $850-\mathrm{hPa}$ pressure level along with the SLP, derived from the CMIP5 models were classified into one of the weather regimes by finding up to three past closest days in the "historical" NCEP/NCAR data set and ascribing the specific future event to the same weather regimes associated with those closest days in the past.
The closest past day is defined according to a distance parameter following the Minkowski metric (Wilks, 2011) in the $N$-dimensional space of forecast and reference vectors. In our case, $N=100$ ( 4 variables in 25 grid points). We stress the contribution and importance of using each of the 25 grid points, individually, in calculating the distances, rather than considering spatially averaged or classification schemes, for example, empirical orthogonal functions over these 25 grid points. The latter would simplify the calculations but at the expense of smoothing the information (Rostkier-Edelstein et al., 2016).

At the next stage, each weather regime is associated with a distribution of daily precipitation amounts at each of the 18-gauge stations. To this end, a parameter is defined so that it can be used to estimate the precipitation at each gauge station. For the present study, the seasonal mean precipitation at each gauge station is chosen as the estimate of the precipitation associated with each weather regime at that station.

The following comment, cited from Rostkier-Edelstein et al. (2016), should be stressed: "There are two sources of uncertainty when ascribing a GCM projection to a weather regime. First, the determination of weather regimes is based on similar but not identical days and, second, the definition of weather regimes is based on a group of close but not identical past states. In considering these factors, not only the closest weather regime is determined but up to three past closest days are considered as well. The downscaled seasonal precipitation at a gauge station is estimated by a weighted-sum of the mean daily precipitation per weather regime at the station according to the frequencies of the weather regimes."

In contrast to the weather regime downscaling method, the analogues downscaling algorithm uses the same variables and grid points, but without first classifying them into specific weather regimes. The predicted daily precipitation at each gauge station is calculated by weight averaging the observed daily precipitation for each of the three past analogues found, in inverse proportion to their squared distances. Seasonal precipitation at each gauge station is the 
(a)

Weather Regime Downscaling (WRD)

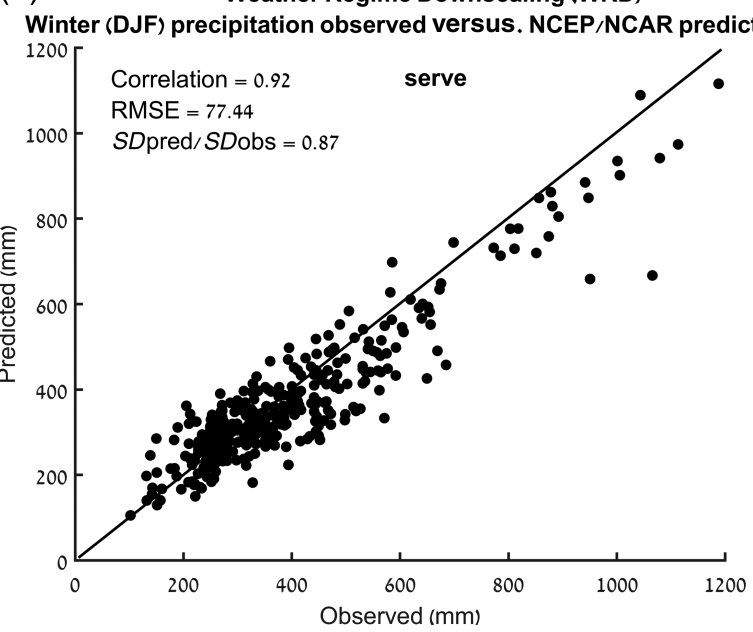

(b)

Analogues Downscaling (AD)
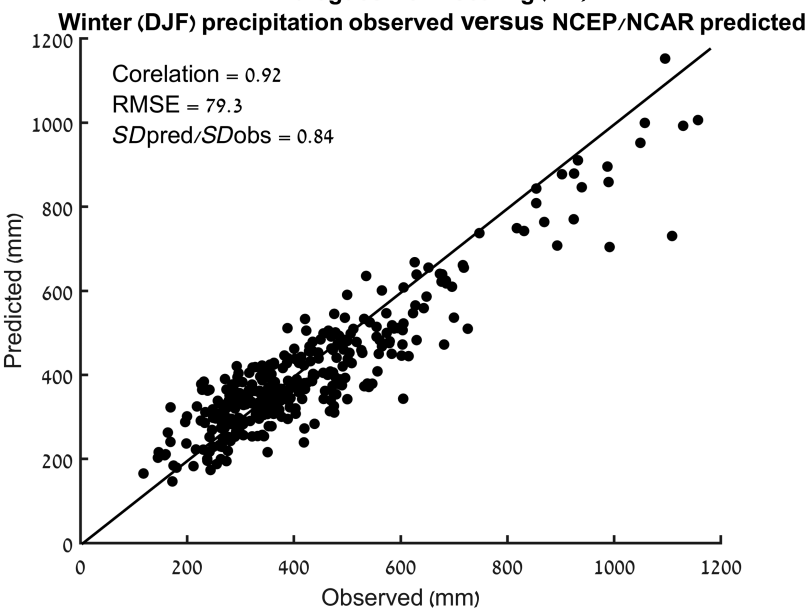

(C) Spring (MAM) precipitation observed stations versus. NNRP predicted

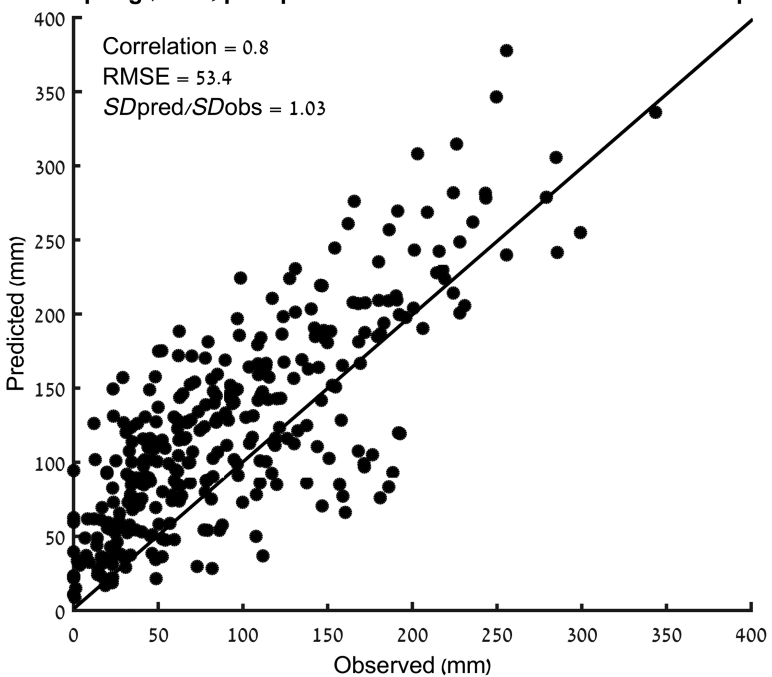

(e)

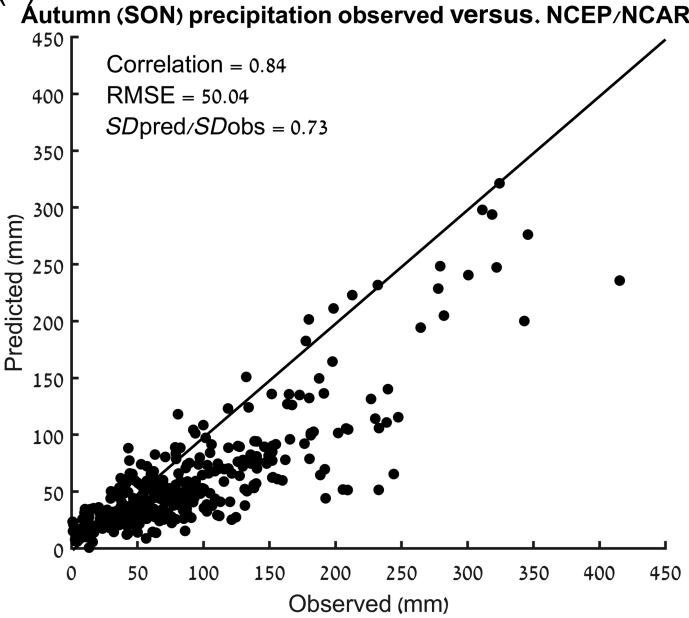

(d)

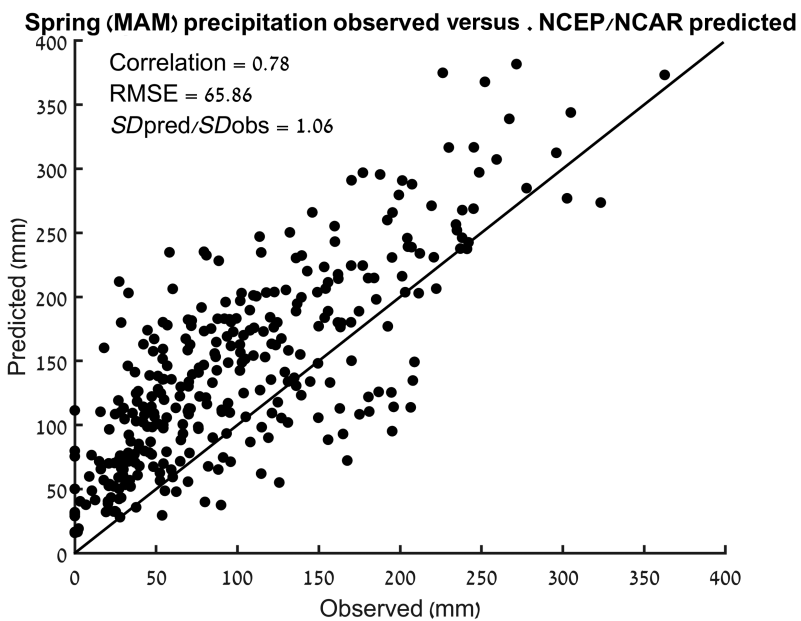

(f)

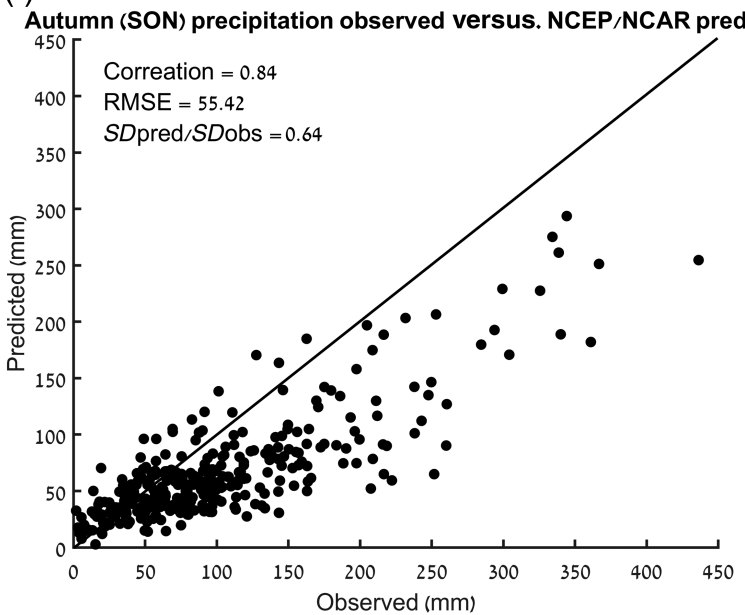

F I G U R E 2 Scatter plots evaluation of seasonal precipitation between the NCEP/NCAR reanalysis (NNRP) and the observations (details in Figure 1 and Table S1), for the period 1991-2008, according the weather regime (a, c, e) and the analogues (b, d, f) statistical downscaling methods. The values are seasonally aggregated for the 18 stations. The panels are (a, b) Winter (DJF); (c, d) Spring (MAM); and (e, f) Autumn (SON). The correlation (R), the root mean $S E$ (RMSE, in $\mathrm{mm}$ ), and the proportion ( $S D$ pred/SDobs) between the predicted $S D(S D$ pred) and the observed $S D$ (SDobs) are given on each separate panel. The 1:1 line is also shown 
sum of the daily amounts. The reader is referred to RostkierEdelstein et al. (2016) for a comprehensive explanation of both downscaling algorithms.

\section{4 | RESULTS}

\subsection{Evaluation of the downscaling algorithms based on NCEP/NCAR reanalysis}

As a first step, the ability of the two algorithms (the weather regimes and the analogues) to downscale seasonal precipitation (winter-DJF, spring-MAM, autumn-SON) is examined (Figure 2). Both algorithms show relatively high correlations $(\mathrm{DJF}=0.92 ;$ MAM $=0.78-0.80$; SON $=0.84$, cross-validated and seasonally aggregated) between observed and predicted seasonal precipitation for 1991-2008. The weather regime downscaling algorithm demonstrates slightly better results in terms of the root mean square error (RMSE) $=\sim 2,12$ and $5 \mathrm{~mm}$ for DJF, MAM and SON, respectively, compared to the analogues algorithm. Also, the weather regime downscaling is better than the analogues method in the proportion between the predicted and observed standard deviations being slightly closer to 1 (Figure 2). Underestimation is found in autumn and overestimation in spring according to both methods (Figures 2, 3 and Table 2). Moreover, it can be generally concluded that for both statistical downscaling algorithms there is not much difference between the results based on variables taken from the $850-\mathrm{hPa}$ level and those according to the 1,000-hPa level, used earlier by Rostkier-Edelstein et al. (2016). Thus, the $850-\mathrm{hPa}$ variables, together with the SLP, are further used in this study.

\section{2 | Evaluation of the seasonal precipitation downscaling according to CMIP5 models}

Figure 3 presents the ability of CMIP5 models to capture the seasonal precipitation distribution for the present period (1986-2005), according to the weather regimes (Figure 3a, $\mathrm{c}, \mathrm{e})$ and the analogues (Figure $3 \mathrm{~b}, \mathrm{~d}, \mathrm{f}$ ) downscaling algorithms, for the different seasons. The models generally underestimate winter precipitation (Figure 3a, b; Table 2) and overestimate spring precipitation, according to both methods (Figure $3 \mathrm{c}$, d; Table 2). The overestimation of spring precipitation is in agreement with the results found according to NCEP/NCAR reanalysis for the present period (Section 4.1). The analogues algorithm can better capture the variance and the extreme outliers in the distributions with respect to the weather regime algorithm (Figure 3; Table 2). This probably results from the fact that past daily precipitation for chosen analogues is used as a predictor, rather than the mean precipitation value that is used for a given weather regime.

\section{3 | Seasonal precipitation projections according to CMIP5}

Figure 4 presents the ensemble mean projections of seasonal precipitation as downscaled by the weather regime (Figure 4a) and analogues (Figure 4b) downscaling algorithms over Israel, for the 21 st century. All distributions display significant reductions in seasonal precipitation, at the 5\% significance level, according to the Wilcoxson Rank Sum test. The RCP8.5 scenario exhibits larger reductions in seasonal precipitation of $\sim 7-18 \%$ and $\sim 14-24 \%$ for the end of the 21 st century, with respect to the RCP4.5, according to the weather regime and the analogues downscaling algorithms, respectively (Table 3). Projections for the end of the century consistently exhibit larger reductions with respect to the mid-century reductions in the rate of $\sim 6-13 \%$ and $12-22 \%$ according to the weather regime and the analogues downscaling algorithms, respectively (RCP8.5; Table 3). The decrease in spring and autumn seasonal precipitation for the end of the 21 st century, under RCP 8.5 , is projected to be stronger than the decrease in winter by $\sim 10$ and $20 \%$ according to the weather regimes and the analogues downscaling algorithms, respectively (Figure 4; Table 3). Most similar findings are reflected in the individual model projections (Figure S1-S6 and Table S2). These projected results are in agreement with the findings of Ziv et al. (2014), who showed a reduction in observed precipitation over Israel for the period 1975-2010, though being significant only in spring. This is also in accordance with Hochman et al. (2018a), who projected seasonal precipitation decrease over Israel for the mid-21st century (RCP4.5) of $\sim 30-50 \%$ in spring and autumn and $\sim 20 \%$ in winter, through dynamically downscaling to $\sim 8 \mathrm{~km}$ grid spacing, using the COSMOCLM regional model. Furthermore, recent studies over Israel have shown that rain gauges can capture the enhancement/ reduction in precipitation downwind/upwind of urban areas, respectively (Halfon et al., 2009; Alpert et al., 2019). If so, statistical downscaling based on observations may be a powerful tool in capturing this effect, which the global models cannot capture.

Figures 5 and 6 display the ensemble mean seasonal precipitation projections as downscaled by the weather regime (Figure 5) and the analogues (Figure 6) downscaling algorithms over the different hydrologic basins of Israel. All distributions display significant reductions in seasonal precipitation at the 5\% significance level, according to the Wilcoxson Rank Sum test. Generally, the illustrations resemble the results found for the entire Mediterranean region of Israel (Figure 4; Table 3). Larger decreases are projected for spring and 

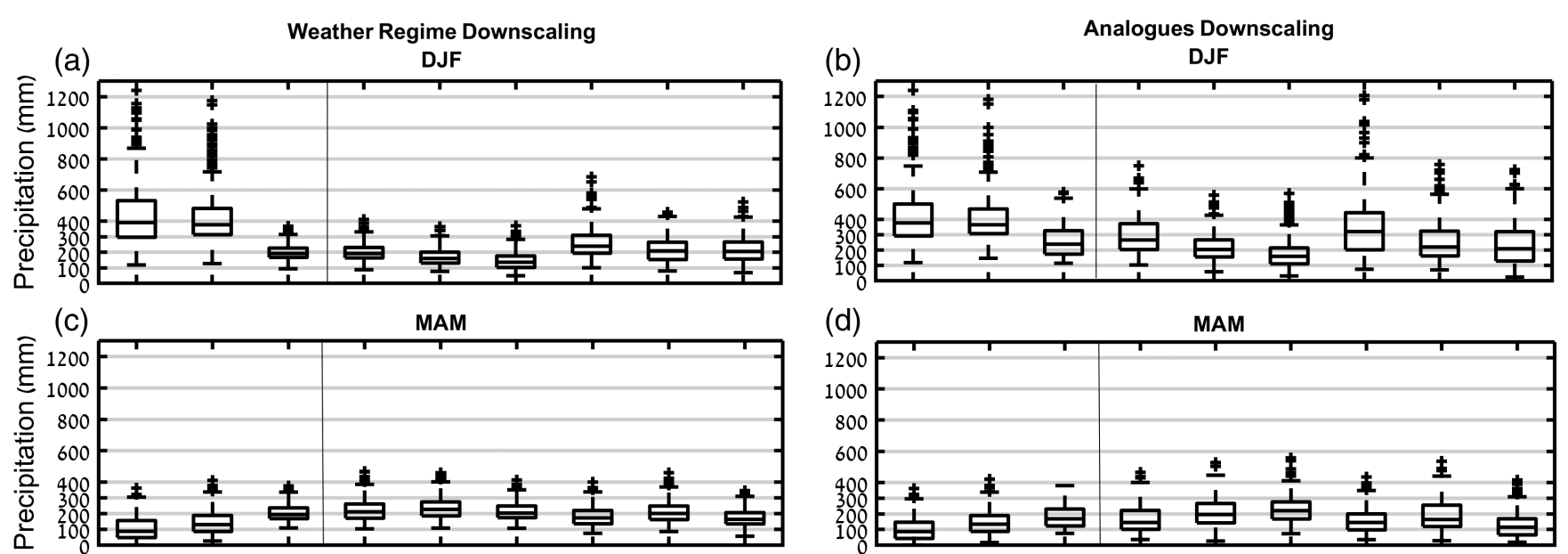

(e)

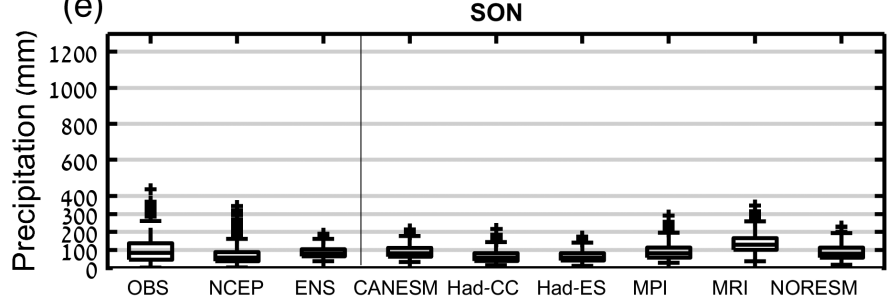

(f)

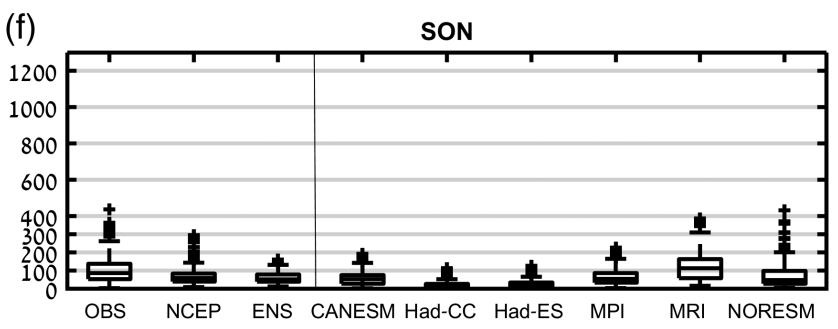

F I G URE 3 Box plots of seasonal precipitation (mm) of the six CMIP5 models (see details in Table 1), their ENSEMBLE mean (ENS), the NCEP/NCAR reanalysis (NCEP), and the observations (OBS) for the period 1991-2005, according to the weather regime (a, c, e) and the analogues (b, d, f) statistical downscaling methods. Panels (a, b) are for the Winter (DJF); (c, d) for the Spring (MAM); and (e, f) for the Autumn (SON). A summary of these results is presented in Table 3

autumn (27-37\% reductions at the end of the century according to RCP8.5) with respect to winter precipitation (25-31\%), mostly for the hydrologic basins of the Sea of Galilee (SG), the Coast (CO), and the Mountains (YA) and less for the Western Galilee (WG) (Table S3; weather regime downscaling). The stronger decrease projected for the SG, the coast and the mountains basins reinforces earlier results (Hochman et al. 2018a), which found that the WG basin would be less affected, in terms of precipitation reductions, than the other basins of Israel. Nevertheless, this is an alarming outcome, since the important aquifers of Israel are located in the above-mentioned three hydrologic basins and the most important are the SG and the Mountains basins.

\section{4 | Projected changes in daily precipitation and in the frequency of wet days}

The significant reductions in seasonal precipitation, presented above, can result from reductions in both the frequency of wet days and/or in the daily mean precipitation yield of wet days. A wet day is defined in the present study following two possible precipitation thresholds; either 0 or $1 \mathrm{~mm}$. Table 4 shows the seasonal changes in the frequency of wet days and in the average daily precipitation of wet days as downscaled by the analogues algorithm, applied to the six CMIP5 models. As mentioned above the analogue method does not classify the CMIP5 variables to weather regimes after calculating the distance between days. Therefore, it can account for changes in the intensity of wet days, as it does not use the mean daily precipitation per weather regime but the daily precipitation of the closest past days. The results are shown for the "historical," that is, the present period (1986-2005) and for the end of the century (RCP8.5; 2081-2100). Results are shown for the end of the 21st century, according to the RCP8.5 scenario. Results for the midcentury and for the RCP4.5 scenario exhibit similar trends, too (not shown).

The CMIP5 models project that the seasonal frequency of wet days and the seasonal daily mean precipitation will both decrease significantly under the binomial and bootstrapping tests at the 5\% significance level, respectively. The largest reductions are found in spring, being $-16 \%$ in the frequency and $-40 \%$ in the mean daily precipitation of wet days (wet day defined as precipitation $>0 \mathrm{~mm}$; Table 4). For the winter, the main rainy season, the projected changes are lower, that is, -9 and $-31 \%$ decreases in the frequency of wet days and in the mean daily precipitation, respectively. These results indicate that the reduction in seasonal precipitation results from projected reduction in 
T A B L E 2 Basic statistics including mean, median, and SD of precipitation (mm) for the winter (DJF), spring (MAM), and autumn (SON) according to the weather regime and analogues downscaling

\begin{tabular}{|c|c|c|c|c|c|c|c|c|c|}
\hline & \multicolumn{3}{|l|}{ DJF } & \multicolumn{3}{|l|}{ MAM } & \multicolumn{3}{|l|}{ SON } \\
\hline OBS & 444 & 391 & 207 & 106 & 88 & 74 & 102 & 84 & 79 \\
\hline \multicolumn{10}{|c|}{ Weather regime downscaling } \\
\hline NCEP/NCAR & 423 & 377 & 180 & 143 & 130 & 76 & 74 & 57 & 59 \\
\hline HadGEM2CC & 169 & 160 & 53 & 236 & 227 & 71 & 65 & 58 & 35 \\
\hline HadGEM2ES & 144 & 136 & 58 & 215 & 203 & 57 & 64 & 57 & 32 \\
\hline MPI & 260 & 239 & 95 & 183 & 173 & 64 & 90 & 81 & 45 \\
\hline MRI & 214 & 209 & 74 & 212 & 201 & 69 & 135 & 129 & 56 \\
\hline NCEP/NCAR & 407 & 365 & 164 & 146 & 134 & 78 & 69 & 58 & 48 \\
\hline ENSEMBLE & 259 & 239 & 100 & 179 & 168 & 67 & 59 & 50 & 28 \\
\hline CANESM & 300 & 266 & 125 & 167 & 144 & 86 & 55 & 51 & 35 \\
\hline HadGEM2CC & 223 & 204 & 89 & 210 & 195 & 91 & 18 & 14 & 17 \\
\hline HadGEM2ES & 175 & 159 & 92 & 230 & 220 & 84 & 25 & 20 & 21 \\
\hline MPI & 359 & 321 & 203 & 153 & 145 & 72 & 63 & 53 & 43 \\
\hline MRI & 258 & 220 & 128 & 187 & 164 & 98 & 121 & 112 & 77 \\
\hline NORESM & 238 & 209 & 142 & 128 & 114 & 74 & 71 & 46 & 70 \\
\hline
\end{tabular}

Note: Evaluation of the six CMIP5 models (Table 1) and their ensemble mean with respect to NCEP/NCAR reanalysis for the present ("historical") period (1986-2005) and observations (OBS) for 1991-2005. Box plots are shown in Figure 3

the frequency of wet days as well as from a projected reduction in the daily precipitation amounts. Note that the downscaled models overestimate the number of wet days in spring and autumn, and underestimate the daily precipitation amounts in all seasons (Table 4). These types of over/ underestimations, when found in global climate models, are at times attributed to the so called "drizzle bias," expressing that the global climate models tend to generate too frequent precipitation, especially in the mid-latitudes due to the high occurrence of days with light precipitation (Stephens et al., 2010; Pendergrass and Hartmann 2014; Samuels et al., 2017). However, in this study, the precipitation variable of the GCMs is not used as a predictor for the downscaled precipitation at the station level. Thus, to a first order, "drizzle bias" should not influence our results. It may influence the results if there is a feedback from the precipitation in the model to our predictors, that is, the SLP, $U$, and $V$ wind components or the temperature at the 850-hPa level. However, it should be stressed that precipitation is highly parametrized in the GCMs, therefore, this should not influence our findings. We suggest that the overestimation in the frequency of wet days and the underestimation of the daily precipitation may be mostly related to the general overestimation of the frequency of Cyprus Lows over the eastern Mediterranean (Hochman et al., 2018c) and the location and depth of these cyclones in the GCMs. These features exert a strong control on daily precipitation over Israel (Saaroni et al., 2010a). As a further test, Table 4 displays the results when defining a wet day as precipitation $\geq 1 \mathrm{~mm}$ (displayed in brackets). Under this slightly higher threshold, the multimodel ensemble mean underestimates the number of wet days in winter and overestimates it in spring. The models further underestimate the mean daily precipitation amounts as found for the $>0 \mathrm{~mm}$ threshold. The largest reductions in the frequency $(-14 \%)$ and mean daily precipitation $(-19 \%)$ of wet days are found in spring and winter, respectively (Table 4).

\section{I SUMMARY AND CONCLUSIONS}

The study investigates projections of seasonal precipitation over Israel and over its main hydrologic basins for the 21st 
(a)

Weather regime downscaling ensemble mean

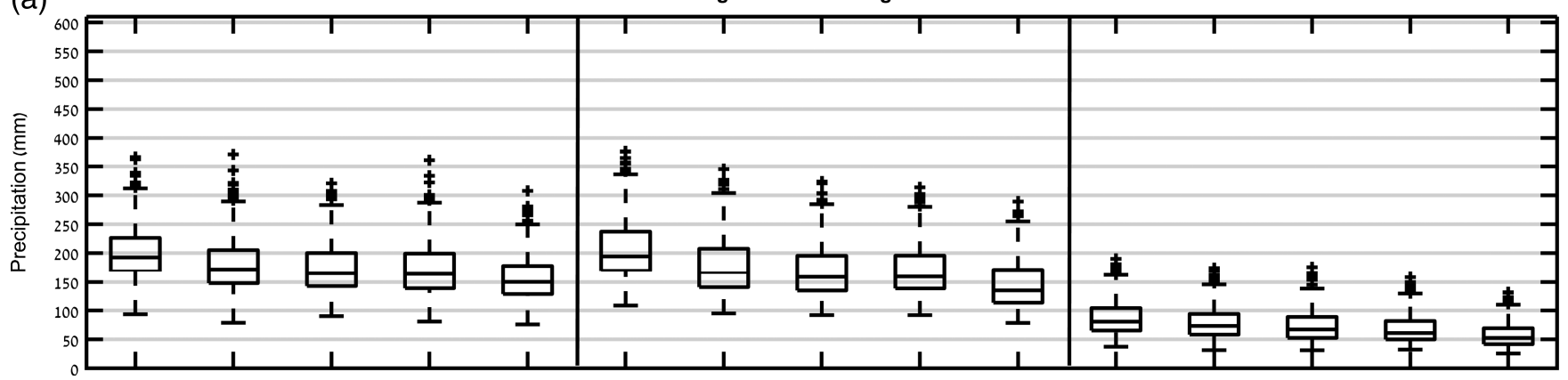

(b)

Analogues downscaling ensemble mean

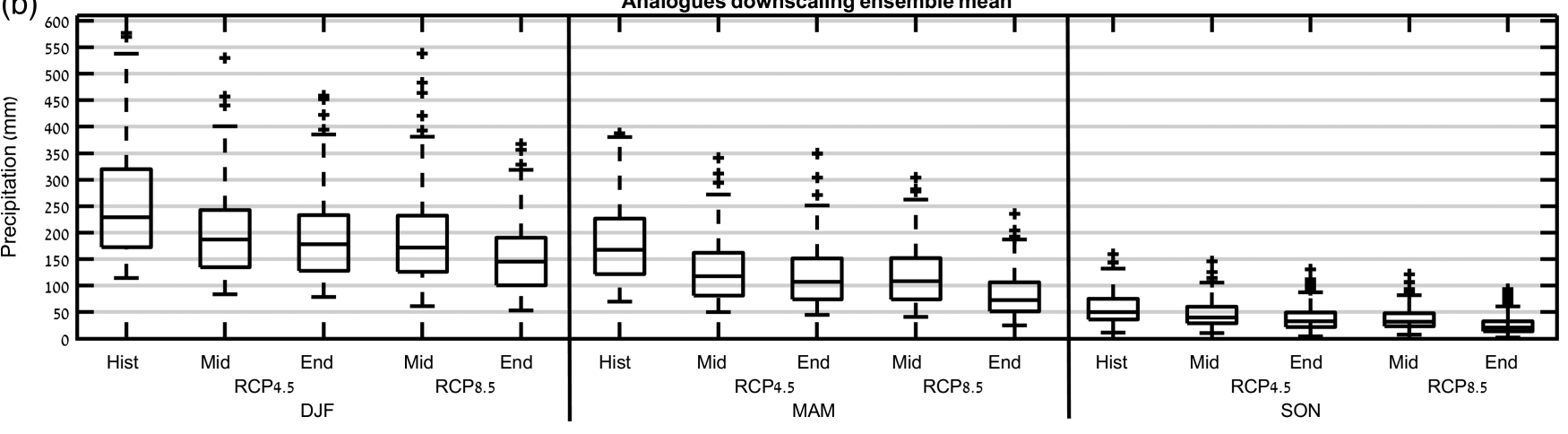

F I G U RE 4 Weather regime (a) and analogues (b) seasonal (winter-DJF, Spring-MAM, Autumn-SON) statistical downscaling ensemble mean projections for RCP4.5 and RCP8.5 over Israel. The periods are the present, denoted as "historical" (Hist) - 1986-2005, the mid-21st century (Mid) - 2046-2065, and the end of the 21st century (End) -2081-2100. A summary of the changes is specified in Table S2

T A B LE 3 The change (difference) in the ensemble mean of the six CMIP5 models for the median seasonal precipitation over Israel for the winter (DJF), spring (MAM) and autumn (SON) (in percentages and in millimeter), according to the weather regime and the analogues downscaling methods for the RCP4.5 and the RCP8.5 scenarios

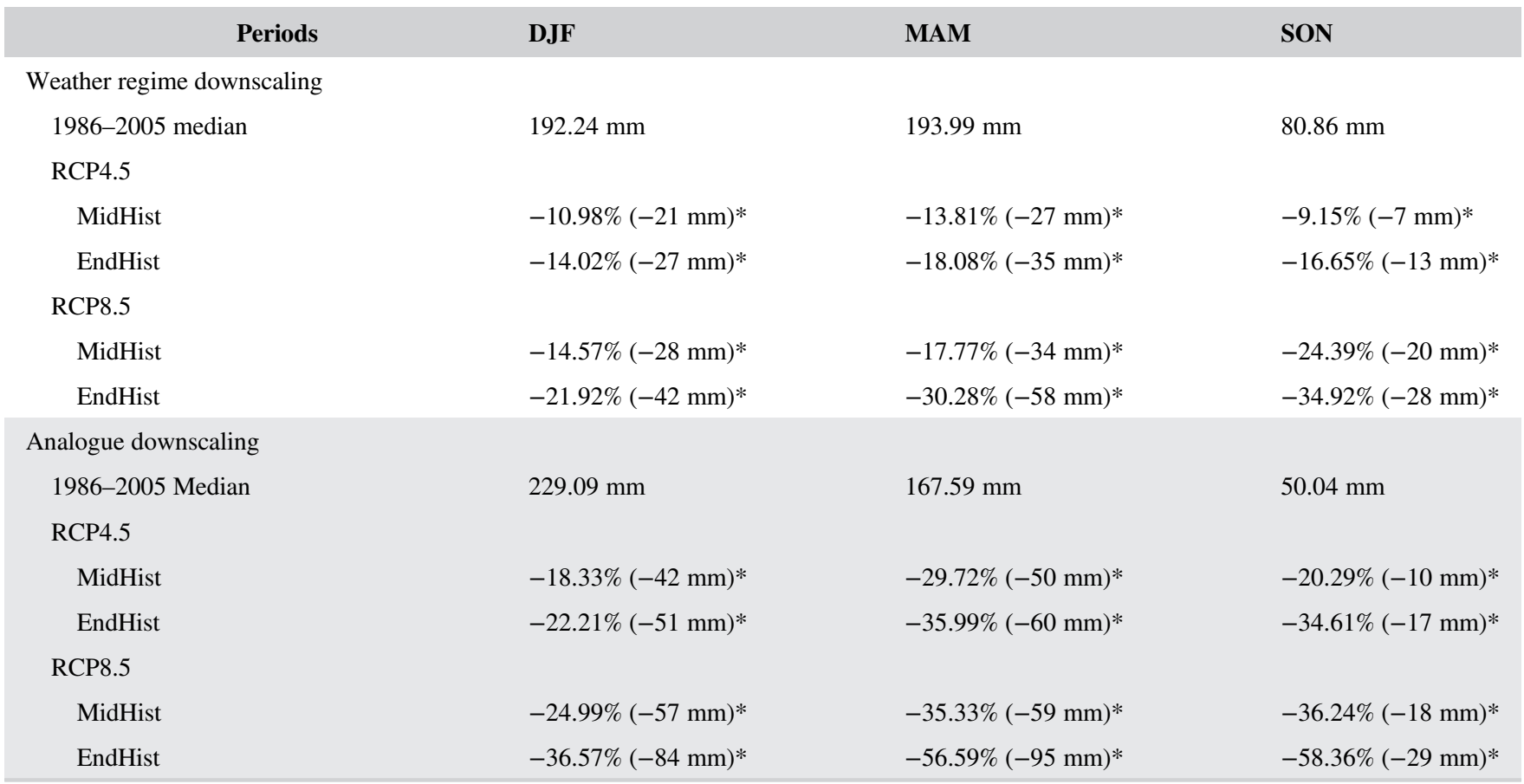

Note: The periods are 1986-2005 (Hist), 2046-2065 (Mid) and 2081-2100 (End). * indicates significant reduction, at the 5\% significance level, (compared to the present period, 1986-2005), using the Wilcoxon Rank-Sum test. Box plots are shown in Figure 4. 
Weather regime downscaling

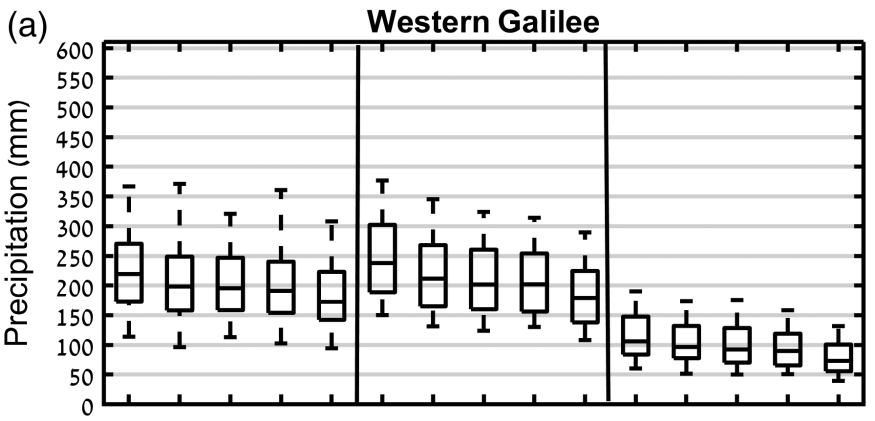

(b)

Sea of Galilee

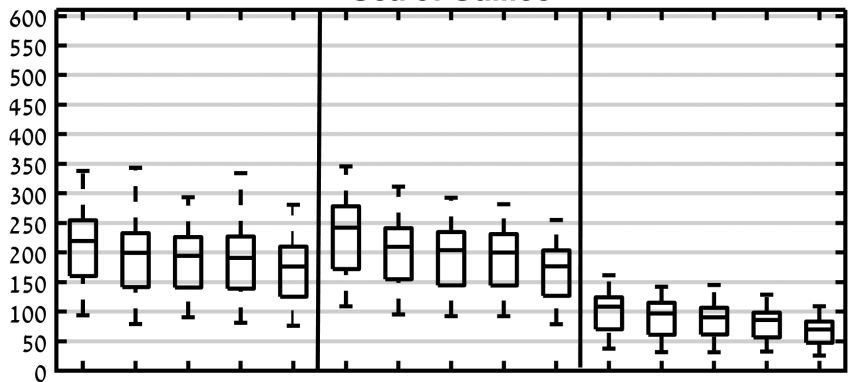

(c)

Coast

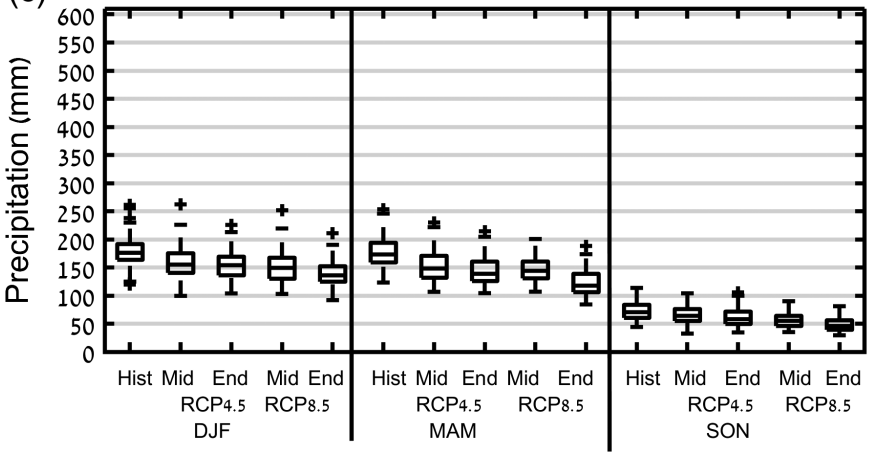

(d)

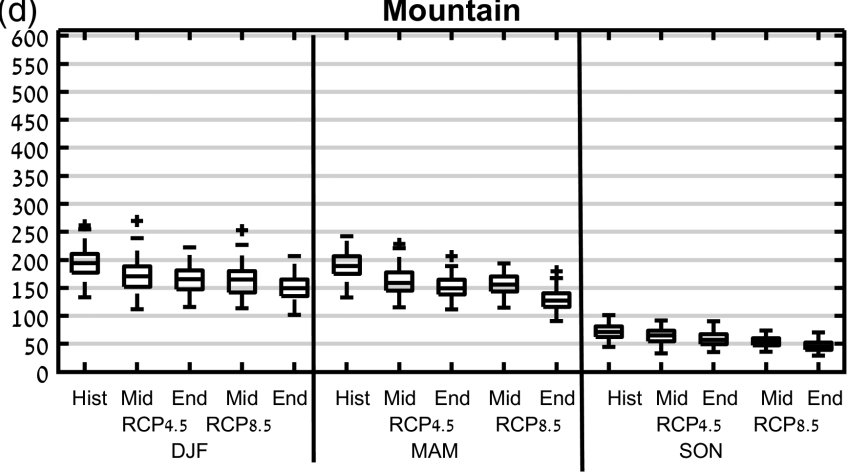

F I G URE 5 Same as Figure 4 but for the four hydrologic basins of Israel according to the weather regime downscaling method. The four hydrologic basins over Israel are (a) western Galilee, (b) Sea of Galilee, (c) coast, (d) mountain. A summary of the changes is specified in Table S3

Analogues downscaling ensemble mean

(a)

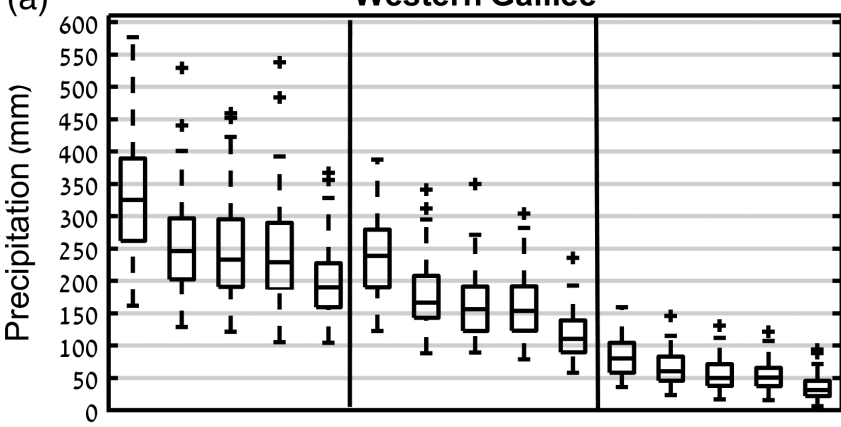

(c)

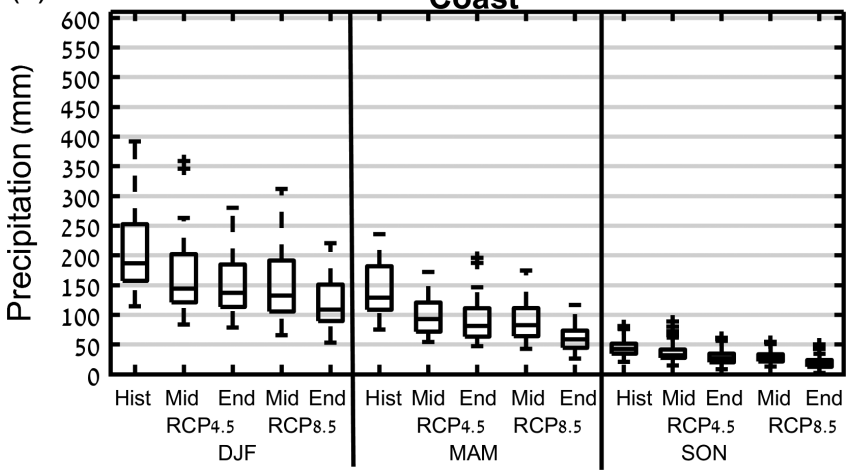

(b)

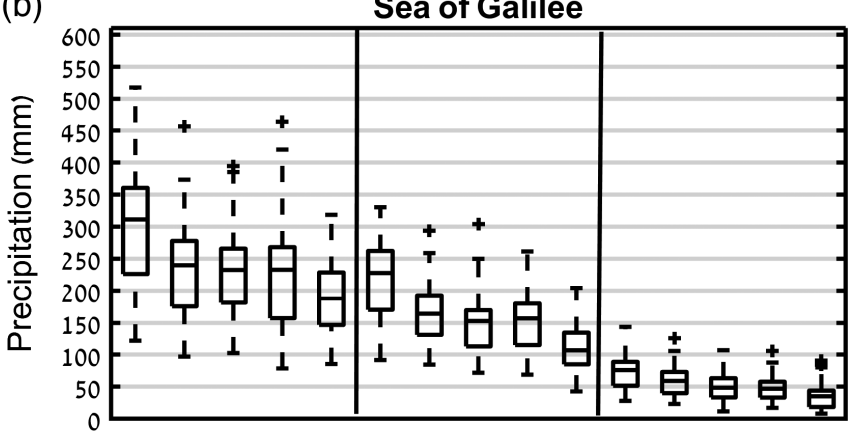

(d)

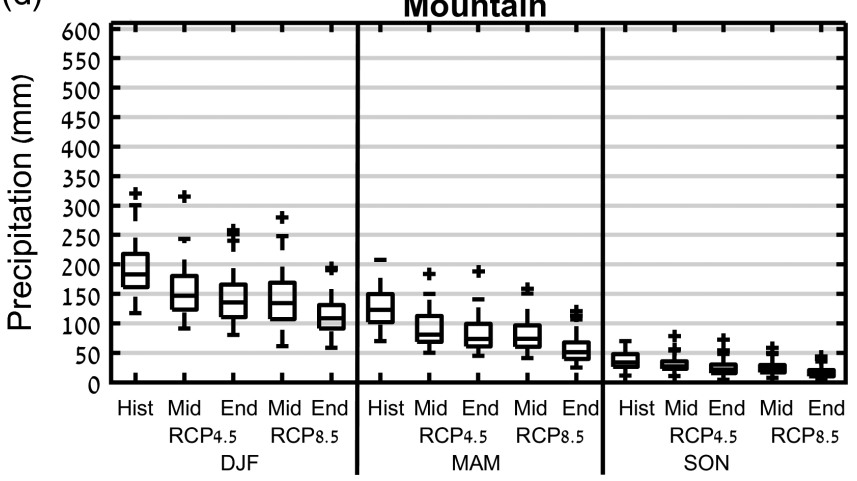

F I G URE 6 Same as Figure 5 but according to the analogues downscaling method. A summary of the changes is specified in Table S3 
T A B LE 4 The seasonal differences in the frequency of wet days and in the average daily precipitation yield on wet days (a wet day is defined as either a day with precipitation $>0 \mathrm{~mm}$ or a day with precipitation $\geq 1 \mathrm{~mm}$ in brackets) as downscaled by the analogues algorithm, applied to CMIP5 models

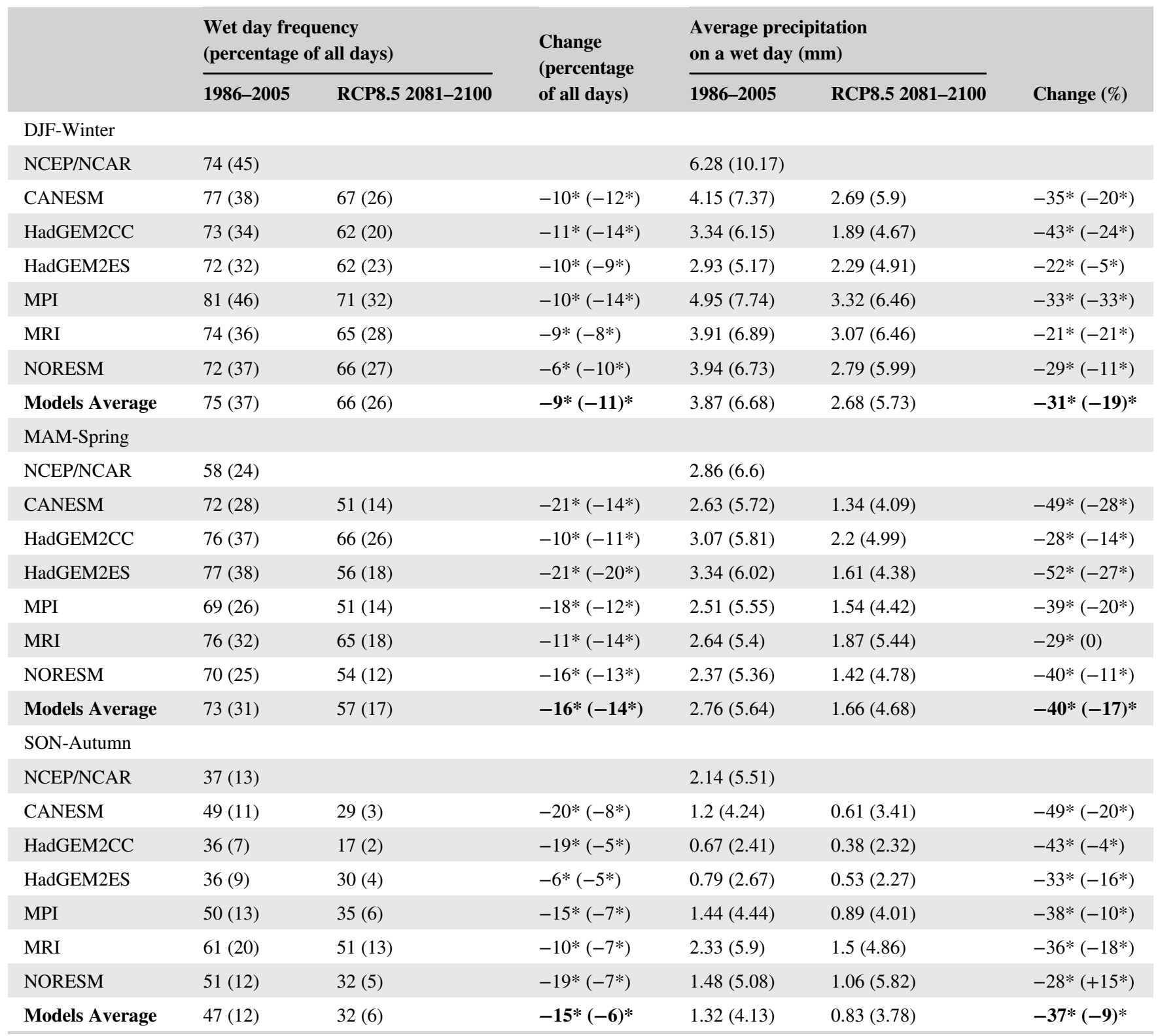

Note: The results based on the NCEP/NCAR reanalysis for the present period (1986-2005) are shown as a reference. * indicates a significant difference at the 5\% significance level using a binomial test for the frequency and a bootstrapping test for the daily precipitation.

Bold numbers in the table were found to be significant.

century, based on outputs of six CMIP5 models. As a caveat, it should be noted that the six models employed here, might be a relatively small number and may thus suffer from uncertainties. However, the models used in this study show quite similar trends in future seasonal precipitation strengthening the confidence in our findings.

Two statistical downscaling methods are applied, one is based on the regional weather types, that is, weather regimes (Rostkier-Edelstein et al., 2016; Hochman et al., 2018c) and the other, on analogues (Rostkier-Edelstein et al., 2016). The downscaling algorithms, applied to the present period, for the NCEP/NCAR reanalysis and the CMIP5 models, were found to reproduce reasonably well the differences in the precipitation amounts between the seasons and between the hydrologic basins. Nevertheless, underestimation is found for the winter and overestimation for the spring resulting from the underestimation of mean daily precipitation in winter and overestimation of the number of wet days in spring. These two outcomes have a strong relation to the frequency, location, and intensity of the Cyprus Lows in the models with respect to the reanalysis. Earlier studies have shown that these features of the Cyprus Lows exert a strong control 
on precipitation in Israel (Saaroni et al., 2010a). Nevertheless, differences in the seasonal precipitation between the present and future period are calculated in this study based only on model simulations and therefore may be considered reasonable estimates.

The results indicate significant reductions in seasonal precipitation projected for the mid and the end of the 21 st century, for all seasons and in all the hydrologic basins of Israel. A larger reduction is found according to the RCP8.5 scenario with respect to the RCP4.5 and for the end-century with respect to mid-century projections. This suggests the strong control that greenhouse gases may have on the seasonal precipitation in Israel. It is found that the decrease in spring and autumn precipitation is projected to be stronger than the decrease in winter, which fits earlier findings ( $\mathrm{Ziv}$ et al. 2014, Hochman et al. 2018a). The larger reduction in the transitional seasons may be a result of a poleward shift of the subtropical highs, toward the Mediterranean Basin, as a part of the expansion of the Hadley cell due to global warming (Lu et al., 2007; Seidel et al., 2008; Johanson and $\mathrm{Fu}, 2009)$. This expansion is also expressed by the bands of negative precipitation trend along the poleward sides of the subtropical highs in both hemispheres (IPCC, 2013). The projected reduction can be also related to the projected migration of the Northern Hemisphere winter storm tracks northward (Chang et al., 2012; Eichler et al., 2013; TamarinBrodsky and Kaspi, 2017), though these studies have not referred to Mediterranean cyclones. Variations in large-scale oscillations, such as the NAO and the East Atlantic-Western Russia (EA-WR) patterns, are known also as modulating the Cyprus Lows (Black, 2012) and thus, may be related with the changes found.

Moreover, this study showed that future reductions in seasonal precipitation result from a decrease in the frequency of wet days, as well as from the projected decrease in daily precipitation amounts. Thus, we suggest that future increase in greenhouse gases has a strong influence on daily precipitation amounts as well as on the frequency of wet days. Projected changes in the intensity of Cyprus Lows and the rainfall intensity associated with them is a subject of further research. Specifically, a larger decrease in seasonal precipitation is projected for the SG, the coastal areas, and the Central Mountainous regions of Israel, located over the main fresh-water aquifers of Israel. The WG basin is projected to be influenced to a smaller extent. The dynamical reasons for the differences in the spatial variability of the projected seasonal precipitation over Israel are a subject of further research.

This study focused on assessing the impacts of climate change, specifically seasonal precipitation, on fresh-water resources in Israel and its main hydrologic basins. Such realistic projections are most necessary for evaluating socio- economic impacts and environmental vulnerability. Here, we compare two advanced statistical downscaling methods with focus on their advantages and disadvantages to acquire regional precipitation projections on different time scales and RCP scenarios. One of the main disadvantages of statistical downscaling techniques is that they rely on the stationary climate assumption (Salvi et al., 2016). We found that the change in the average Minkowski metric, that is, the daily similarity metric, changes by an average of $1-4 \%$ in the analogue method between the present period and the end of the 21st century, according to RCP8.5. This is a relatively small change; thus, the stationary assumption may be considered reasonable here.

The statistical downscaling methods applied in our study are general and can be easily transferred to other regions where long-term data sets of observed precipitation are available. In particular, the same variables from global models are expected to be adequate in areas where precipitation is dominated by extratropical cyclones and low-pressure troughs. The analogues downscaling algorithm may be applied straightforward using the same variables. The weather regimes algorithm may be customized for other regions and objective methods may be used to overcome the need for experts' classification (see, e.g., Berkovic, 2017).

One of the most important outcomes of this study, along with other regional studies, is its applicability to serve as a tool for priority setting and policy formulation toward climate adaptation strategies at the national, regional, and local levels, taking into account the associated uncertainties, described above.

\section{ACKNOWLEDGMENTS}

The authors thank the Tel-Aviv University President and Mintz foundation. This study was also partially supported by cooperation in the international virtual institute DESERVE (Dead Sea Research Venue), funded by the German Helmholtz Association, the Israel Science Foundation (ISF, grant no. 1123/17), the Water Authority of Israel. This work is a contribution to the HyMeX program.

\section{ORCID}

Assaf Hochman (10) https://orcid.org/0000-0002-9881-1893 Hadas Saaroni (10 https://orcid.org/0000-0001-6369-1847 Dorita Rostkier-Edelstein (10 https://orcid.org/0000-00032191-1236

\section{REFERENCES}

Alpert, P. (1991) The uniqueness of Jerusalem climate. Bulletin of the American Meteorological Society, 72, 228-231. 
Alpert, P., Krichak, S.O., Shafir, H., Haim, D. and Osetinsky, I. (2008) Climatic trends to extremes employing regional modeling and statistical interpretation over the E. Mediterranean. Global and Planetary Change, 63, 163-170.

Alpert, P., Neeman, B.U. and Shay-El, Y. (1990) Climatological analysis of Mediterranean cyclones using ECMWF data. Tellus, 42A, 65-77.

Alpert, P., Osetinsky, I., Ziv, B. and Shafir, H. (2004a) Semi-objective classification for daily synoptic systems: Application to the Eastern Mediterranean climate change. International Journal of Climatology, 24, 1001-1011.

Alpert, P., Osetinsky, I., Ziv, B. and Shafir, H. (2004b) A new season's definition based on classified daily synoptic systems: an example for the eastern Mediterranean. International Journal of Climatology, 24, 1013-1021. https://doi.org/10.1002/joc.1037.

Alpert, P., Price, C., Krichak, S.O., Ziv, B., Saaroni, H., Osetinsky, I., Barkan, J. and Kishcha, P. (2005) Tropical tele-connections to the Mediterranean climate and weather. Advances in Geosciences, 2, 157-160.

Alpert, P., Radian, R., Halfon, N. and Levin, Z. (2019) Urban rainfall anomaly under intensive development, 1949-2018, Case of TelAviv, Israel. Atmosphere, 10, 163.

Berkovic, S. (2016) Synoptic classes as a predictor of hourly surface wind regimes: the case of the central and Southern Israeli coastal plains. Journal of Applied Meteorology and Climatology, 55, 1533-1547.

Berkovic, S. (2017) Winter wind regimes over Israel using selforganizing maps. Journal of Applied Meteorology and Climatology, 56, 2671-2691.

Black, E. (2009) The impact of climate change on daily precipitation statistics in Jordan and Israel. Atmospheric Science Letters, 10, 192-200. https://doi.org/10.1002/asl.233.

Black, E. (2012) The influence of the North Atlantic Oscillation and European circulation regimes on the daily to inter-annual variability of winter precipitation in Israel. International Journal of Climatology, 32(11), 1654-1664. https://doi.org/10.1002/joc.2383.

Chang EKM, Guo Y, Xia X. 2012. CMIP5 multi-model ensemble projection of storm track change under global warming. Journal of Geophysical Research Atmosphere 117: D23118. DOI: https://doi. org/10.1029/2012jd018578

Chenoweth, J., Hadjinicolaou, P., Bruggeman, A., Lelieveld, J., Levin, Z., Lange, M., Xoplaki, E. and Hadjikakou, M. (2011) Impact of climate change on the water resources of the eastern Mediterranean and Middle East region: Modeled 21st century changes and implications. Water Resources Research, 47, W06506. https://doi.org/10.1029/2010WR010269.

Davini, P. and Cagnazzo, C. (2014) On the misinterpretation of the North Atlantic oscillation in CMIP5 models. Climate Dynamics, 43 (5-6), 1497-1511.

Dayan, U., Tubi, A. and Levy, I. (2012) On the importance of synoptic classification methods with respect to environmental phenomena. International Journal of Climatology, 32, 681-694.

Diskin, M.H. (1970) Factors affecting variations of mean annual rainfall in Israel. Bulletin of the International Association of Scientific Hydrology, 5, 41-49.

Eichler, T.P., Gaggini, N. and Pan, Z. (2013) Impacts of global warming on Northern Hemisphere winter storm tracks in the CMIP5 model suite. Journal of Geophysical Research Atmosphere, 118(10), 3919-3932. https://doi.org/10.1002/jgrd.50286.
Evans, J.P. (2010) Global warming impact on the dominant precipitation processes in the Middle East. Theoretical and Applied Climatology, 99, 389-402. https://doi.org/10.1007/s00704-009-0151-8.

Fowler, H.J., Blenkinsop, S. and Tebaldi, C. (2007) Linking climate change modeling to impacts studies: recent advances in downscaling techniques for hydrological modeling. International Journal of Climatology, 27, 1547-1578. https://doi.org/10.1002/joc.1556.

Giorgi, F. and Gutowski, W.J. (2015) Regional dynamical downscaling and the CORDEX initiative. Annual Review of Environment and Resources, 40, 467-490.

Giorgi, F., Jones, C. and Asrar, G.R. (2009) Addressing climate information needs at the regional level: the CORDEX Framework. WMO Bulletin, 58, 175.

Goldreich Y. (2003) The Climate of Israel: Observation, Research and Application, Israel: Springer, p. 298.

Goldreich, Y., Moses, H. and Rosenfeld, D. (2004) Radar analysis of cloud systems and their rainfall yield in Israel. Israel Journal of Earth Sciences, 53, 63-76.

Halfon, N., Levin, Z. and Alpert, P. (2009) Temporal rainfall fluctuations in Israel and their possible link to urban and air pollution effects. Environmental Research Letters, 4, 12.

HMSO. (1962) Weather in the Mediterranean I: general meteorology, 2nd edition. London: Her Majesty's Stationery Office, p. 362.

Hochman, A., Alpert, P., Harpaz, T., Saaroni, H. and Messori, G. (2019) A new dynamical systems perspective on atmospheric predictability: eastern Mediterranean weather regimes as a case study. Science Advances, 5: eau0936. https://doi.org/10.1126/sciadv. aau0936.

Hochman, A., Harpaz, T., Saaroni, H. and Alpert, P. (2018b) The seasons' length in $21^{\text {st }}$ century CMIP5 projections over the eastern Mediterranean. International Journal of Climatology, 38(6), 2627-2637. https://doi.org/10.1002/joc.5448.

Hochman, A., Harpaz, T., Saaroni, H. and Alpert, P. (2018c) Synoptic classification in 21st century CMIP5 predictions over the Eastern Mediterranean with focus on cyclones. International Journal of Climatology, 38, 1476-1483. https://doi.org/10.1002/joc.5260.

Hochman, A., Mercogliano, P., Alpert, P., Saaroni, H. and Bucchignani, E. (2018a) High-resolution projection of climate change and extremity over Israel using COSMO-CLM. International Journal of Climatology. 38(14): 5095-5106. https://doi.org/ 10.1002/joc.5714.

Huth, R. (2019) Value: validating and integrating downscaling methods for climate change research. International Journal of Climatology, 39(9), i-iv. https://doi.org/10.1002/joc.5756.

IPCC (2013) Climate Change 2013: The Physical Science Basis. Contribution of Working Group I to the Fifth Assessment Report of the Intergovernmental Panel on Climate Change [Stocker, T.F., D. Qin, G.-K. Plattner, M. Tignor, S.K. Allen, J. Boschung, A. Nauels, Y. Xia, V. Bex and P.M. Midgley (eds.)]. Cambridge University Press, Cambridge, UK, 1535 pp, DOI:https://doi.org/10. 1017/CBO9781107415324.

Israel Meteorological Service (IMS). (2018). Annual precipitation (1981-2010) map of Israel, Climate Atlas of Israel. Available at: http://www.ims.gov.il/NR/rdonlyres/FEE1B975-72C5-45EFB67A-672FC83C6FE2/0/19812010.pd [ותמשקעים.pd]

Johanson, C.M. and Fu, Q. (2009) Hadley cell widening: Model simulations versus observations. Journal of Climate, 22, 2713-2725.

Kalnay, E., Kanamitsu, M., Kistler, R., Collins, W., Deaven, D., Gandin, L., Iredell, M., Saha, S., White, G., Woollen, J., Zhu, Y., 
Chelliah, M., Ebisuzaki, W., Higgins, W., Janowiak, J., Mo, K.C., Ropelewski, C., Wang, J., Leetmaa, A., Reynolds, R., Jenne, R. and Joseph, D. (1996) The NCEP/NCAR 40-Year reanalysis project. Bulletin of the American Meteorological Society, 77, 437-471.

Katsnelson, J. (1964) The variability of annual precipitation in Palestine. Archiv für Meteorologie, Geophysik und Bioklimatologie, 13B, 163-172.

Kutiel, H. (1987) Rainfall variations in the Galilee (Israel). IVariations in the spatial distribution in the periods 1931-1960 and 1951-1980. Journal of Hydrology, 94, 331-344.

Lanzante, J.R., Dixon, K.W. and Nath, M.J. (2018) Some pitfalls in statistical downscaling of future climate. Bulletin of the American Meteorological Society, 99, 791-803.

Laprise, R., et al. (2008) Challenging some tenets of regional climate modelling. Meteorology and Atmospheric Physics, 100, 3-22.

Lelieveld, J., Hadjinicolaou, P., Kostopoulou, E., Chenoweth, J., Maayar, M., Giannakopoulos, C., Hannides, C., Lange, M., Tanarhte, M., Tyrlis, E. and Xoplaki, E. (2012) Climate change and impacts in the Eastern Mediterranean and the Middle East. Climatic Change, 114, 667-687. https://doi.org/10.1007/s10584-0120418-4.

Lionello, P., Abrantes, F., Gacic, M., Planton, S., Trigo, R. and Ulbrich, U. (2014) The climate of the Mediterranean region: research progress and climate change impacts. Regional Environmental Change, 14, 1679-1684.

Lorenz, E.N. (1969) Atmospheric predictability as revealed by naturally occurring analogues. Journal of the Atmospheric Sciences, 26, 636-646.

Lu J, Vecchi GA, Reichler T. 2007. Expansion of the Hadley cell under global warming. Geophysical Research Letters 34: L06805. DOI: https://doi.org/10.1029/2006GL028443

Maraun, D., Wetterhall, F., Ireson, A.M., Chandler, R.E., Kendon, E.J., Widmann, M., Brienen, S., Rust, H.W., Sauter, T., Themessl, M., Venema, V.K.C., Chun, K.P., Goodess, C.M., Jones, R.G., Onof, C., Vrac, M. and Thiele-Eich, I. (2010) Precipitation downscaling under climate change. Recent developments to bridge the gap between dynamical models and the end user. Reviews of Geophysics, 48, RG3003.

Maraun, D. and Widmann, M. (2018) Statistical Downscaling and Bias Correction for Climate Research. Cambridge, UK: Cambridge University Press. https://doi.org/10.1017/9781107588783.

Maraun, D., Widmann, M., Gutiérrez, J.M., Kotlarski, S., Chandler, R. E., Hertig, E., Wibig, J., Huth, R. and Wilcke, R.A. (2015) VALUE: A framework to validate downscaling approaches for climate change studies. Earth's Future, 3, 1-14. https://doi.org/10. 1002/2014EF000259.

Morin, E. (2011) To know what we cannot know: global mapping of minimal detectable absolute trends in annual precipitation. Water Resources Research, 47, W07505.

Önol B, Semazzi FHM. 2009. Regionalization of climate change simulations over the eastern Mediterranean. Journal of Climate 22: 1944-1961. DOI: 618 https://doi.org/10.1175/2008JCL I1807.1

Peleg, N., Bartov, M. and Morin, E. (2015) CMIP5-predicted climate shifts over the East Mediterranean: implications for the transition region between Mediterranean and semi-arid climates. International Journal of Climatology, 35, 2144-2153. https://doi.org/10.1002/ joc. 4114 .
Peleg, N., Molnar, P., Burlando, P. and Fatichi, S. (2019) Exploring stochastic climate uncertainty in space and time using a gridded hourly weather generator. Journal of Hydrology, 571, 627-641.

Pendergrass, A.G. and Hartmann, D.L. (2014) Two modes of change of the distribution of rain. Journal of Climate, 27, 8357-8371.

Rostkier-Edelstein, D., Kunin, P., Hopson, T.M., Yubao, L. and Givati, A. (2016) Statistical downscaling of seasonal precipitation in Israel. International Journal of Climatology, 36, 590-606.

Saaroni, H., Halfon, N., Ziv, B., Alpert, P. and Kutiel, H. (2010a) Links between the rainfall regime in Israel and location and intensity of Cyprus Lows. International Journal of Climatology, 30, 1014-1025.

Saaroni, H., Ziv, B., Harpaz, T. and Lempert, J. (2019) Dry events in the winter in Israel and its linkage to synoptic and large-scale circulations. International Journal of Climatology, 39(2), 1054-1071. https://doi.org/10.1002/joc.5862.

Saaroni, H., Ziv, B., Lempert, J., Gazit, Y. and Morin, E. (2015) Prolonged dry spells in the Levant region: climatologic-synoptic analysis. International Journal of Climatology, 35(9), 2223-2236.

Saaroni, H., Ziv, B., Osetinsky, I. and Alpert, P. (2010b) Factors governing the inter-annual variation and the long-term trend of the 850-hPa temperature over Israel. Quarterly Journal of the Royal Meteorological Society, 136, 305-318.

Saaroni, H., Ziv, B. and Uman, T. (2010c) Does a synoptic classification indicate the $\mathrm{NO}_{\mathrm{x}}$ pollution potential? The case of the metropolitan area of Tel Aviv, Israel. Water Air and Soil Pollution, 207, 139-155.

Saha, S., Nadiga, S., Thiaw, C., Wang, J., Wang, W., Zhang, Q., van den Dool, H.M., Pan, H.L., Moorthi, S., Behringer, D., Stokes, D., Pena, M., Lord, S., White, G., Ebisuzaki, W., Peng, P. and Xie, P. (2006) The NCEP climate forecast system. Journal of Climate, 19, 3483-3517.

Salvi, K., Ghosh, S. and Ganguly, A.R. (2016) Credibility of statistical downscaling under nonstationary climate. Climate Dynamics, 46, 1991-2023.

Samuels, R., Harel, M. and Alpert, P. (2013) A new methodology for weighting high resolution model simulations to project future rainfall in the Middle East. Climate Research, 57, 51-60. https://doi. org/10.3354/cr01147.

Samuels, R., Hochman, A., Baharad, A., Givati, A., Levi, Y., Yosef, Y., Saaroni, H., Ziv, B., Harpaz, T. and Alpert, P. (2017) Evaluation and projection of extreme precipitation indices in the Eastern Mediterranean based on CMIP5 multi model ensemble. International Journal of Climatology, 38(5), 2280-2297. https:// doi.org/10.1002/joc.5334.

Schädler, G. and Sasse, R. (2006) Analysis of the connection between precipitation and synoptic-scale processes in the Eastern Mediterranean using self-organizing maps. Meteorologische Zeitschrift, 15, 273-278.

Seidel, D.J., Fu, Q., Randel, W.J. and Reichler, T.J. (2008) Widening of the tropical belt in a changing climate. Nature Geoscience, 1, 21-24.

Sharon, D. and Kutiel, H. (1986) The distribution of rainfall intensity in Israel, its regional and seasonal variations and its climatological evaluation. International Journal of Climatology, 6, 277-291.

Shay-El, Y. and Alpert, P. (1991) A diagnostic study of winter diabatic heating in the Mediterranean in relation to cyclones. Quarterly Journal of the Royal Meteorological Society, 117, 715-747. 
Sperber, K.R., Annamalai, H., Kang, S.I., Kitoh, A., Moise, A., Turner, A., Wang, B. and Zhou, T. (2013) The Asian summer monsoon: an inter-comparison of CMIP5 vs. CMIP3 simulations of the late 20th century. Climate Dynamics, 41, 2711-2744.

Stein, U. and Alpert, P. (1991) Inclusion of sea moisture flux in the Anthes-Kuo cumulus parametrization. Contri Atmosphere Physics, 64, 231-243.

Stephens GL, L'Ecuyer T, Forbes R, Gettelmen A, Golaz JC, BodasSalcedo A, Suzuki K, Gabriel P, Haynes J. 2010. Dreary state of precipitation in global models. Journal of Geophysical Research 115: D24211. DOI:https://doi.org/10.1029/2010JD014532.

Tamarin-Brodsky, T. and Kaspi, Y. (2017) Enhanced poleward propagation of storms under climate change. Nature geoscience, 10: 908-913. https://doi.org/10.1038/s41561-017-0001-8.

Taylor, K.E.R., Stouffer, J. and Meehl, G.A. (2012) An overview of CMIP5 and the experiment design. Bulletin of the American Meteorological Society, 93, 485-498.

Trigo, I.F., Davies, T.D. and Bigg, G.R. (1999) Objective climatology of cyclones in the Mediterranean region. Journal of Climate, 12, $1685-1696$.

Van-Vuuren, D.P., Edmonds, J.A., Kainuma, M., Riahi, K. and Weyant, J. (2011) A special issue on the RCPs. Climatic Change, 109, 1-4. https://doi.org/10.1007/s10584-011-0157-y.

Velasquez, J.A., Troin, M., Caya, D. and Brissette, F. (2015) Evaluating the time-invariance hypothesis of climate model bias correction: implications for hydrological impact studies. Journal of HydroMeteorology, 16, 2013-2026. https://doi.org/10.1175/JHM-D-140159.1.

Warner, T.T. (2010) Numerical Weather and Climate Prediction. Cambridge, UK: Cambridge University Press. https://doi.org/10.1017/ CBO9780511763243.

Warner, T.T. (2011) Quality assurance in atmospheric modeling. Bulletin of the American Meteorological Society, 92, 1601-1610. https:// doi.org/10.1175/BAMS-D-11-00054.

Wilby, R.L. and Wigley, T.M.L. (1997) Downscaling general circulation model output: a review of methods and limitations. Progressions in Physical Geography, 21, 530-548.

Wilks, D.S. (2011) Statistical Methods in the Atmospheric Sciences. San Diego, CA: Academic Press.
Zhang, X., Aguilar, E., Sensoy, S., Melkonyan, H., Tagiyeva, U., Ahmed, N., Kutaladze, N., Rahimzadeh, F., Taghipour, A., Hantosh, T.H., Alpert, P., Semawi, M., Ali, M.K., Al-Oulan, A.-S. M.H.Z., Zatari, T., Al Dean Khelet, I., Hamoud, S., Sagir, R., Demircan, M., Eken, M., Adiguzel, M., Alexander, L., Peterson, T. C. and Wallis, T. (2005) Trends in middle east climate extreme indices from 1950 to 2003. Journal of Geophysical Research, 110, D22104. https://doi.org/10.1029/2005JD006181.

Ziv, B., Dayan, U., Kushnir, Y., Roth, C. and Enzel, Y. (2006) Regional and global atmospheric patterns governing rainfall in the southern Levant. International Journal of Climatology, 26(1), $55-73$.

Ziv, B., Harpaz, T. and Saaroni, H. (2015) A new methodology for identifying daughter cyclogenesis-application for the Mediterranean Basin. International Journal of Climatology, 35(13), 3847-3861.

Ziv, B., Saaroni, H., Pargament, R., Harpaz, T. and Alpert, P. (2014) Trends in rainfall regime over Israel, 1975-2010, and their relationship to large-scale variability. Regional Environmental Change, 14(5), 1751-1764. https://doi.org/10.1007/s10113-0130414-x.

Zorita, E. and von Storch, H. (1999) The analog method-a simple statistical downscaling technique: comparison with more complicated methods. Journal of Climate, 12, 2474-2489.

\section{SUPPORTING INFORMATION}

Additional supporting information may be found online in the Supporting Information section at the end of this article.

How to cite this article: Hochman A, Kunin $P$, Alpert P, Harpaz T, Saaroni H, Rostkier-Edelstein D. Weather regimes and analogues downscaling of seasonal precipitation for the 21 st century: A case study over Israel. Int J Climatol. 2020;40:2062-2077. https://doi.org/10.1002/joc.6318 